\title{
Ceviz (Juglans regia L.) floem ekstraktının tohum çimlenmesi üzerine etkilerinin belirlenmesi
}

\section{Turan KARADENIZ ${ }^{1}$}

${ }^{1}$ Ordu Üniversitesi, Ziraat Fakültesi, Bahçe Bitkileri Bölümü, 52200, ORDU

Alınış tarihi:08 Ağustos 2011, Kabul tarihi: 20 Ekim 2011

Sorumlu yazar: Turan KARADENİ, e-posta: turankaradeniz@hotmail.com

\section{Özet}

$\mathrm{Bu}$ araştırmada, cevizin floem ekstraktının tohum çimlenmesi ve fide gelişimi üzerine etkileri araştırılmıştır. Kullanılan ceviz floem ekstraktının toplam fenolik bileşik miktarı $13.07 \mathrm{mg} / \mathrm{g}^{\prime} \mathrm{d} ı$. Cevizin yıllık sürgünlerinin floem ekstraktının, hıyar tohumunun çimlenmesi ve fide gelişimi üzerine önemli derecede engelleyici bir rol oynadığı görülmüștür.

Anahtar Kelimeler: Ceviz, fenolik bileşikler, floem ekstraktı, çimlenme

Determination of the effects of walnut Uuglans regia L.) phloem tissue extraction on the seed germination

\begin{abstract}
In this study the effects of the pholem extract of walnut on seed germination and seedling development were investigated. As germination medium, the phloem of walnut-year shoots used in extraction. The extract used in the phloem was 13.07 $\mathrm{mg} / \mathrm{g}$ level as the total phenolic compound. In experiment, the walnut-year shoots phloem extract was to be an inhibitory effect on seeds germination and growing.
\end{abstract}

Keywords: Walnut, phenolic compounds, phloem extract, germination

\section{Giriş}

Bitkilerde önemli bir doku olan floem, birçok araştırıcı tarafından incelenmiş ve floemde bulunan maddeler belirlenmeye çalışılmıştır. Nitekim, Tanrısever (1982a) kiraz grubu prunus türlerinin floem dokusunun flavan içeriklerini belirleyerek, bu bileşiklerle büyüme gücü arasındaki ilişkileri ortaya koymuştur. Yine, yapılan başka bir araștırmada, Prunus avium'da flavanların vasküler kambiyum ve fellogende fazla bulunduğu kaydedilmektedir (Tanrisever, 1982b).

Fenolik bileşiklerin, bazı araştırıcılara göre, büyümeyi olumlu yönde etkilediği, bazılarına göre de büyümeyi engelledikleri kaydedilmektedir. Tanrisever (1982a)'e göre, monofenoller Indol Asetik Asit (IAA)'nın parçalanmasını teşvik ederek büyümeyi engellenmekte, difenoller ise, bu parçalanmayı önleyerek gelişmeyi teşvik etmektedir.

Hansman ve Novoa (1986), fenolik bileşiklerin üretken kallüs kültürünün şekillenmesini engellediklerini, ortama Naftalen Asesit Asit (NAA) ilave edildiği zaman kallüs kültürünün büyük ölçüde üretken duruma geçtiğini bildirmektedir. Başka bir çalışmada, kallüs kültürü gelişmesinin, cevizin ksilem özsuyu içerisinde bulunan juglon tarafından engellendiği kaydedilmektedir (Prataviera et al., 1983). Diğer taraftan, Clark et al.(1990), siyah cevizin olgunlaşmamış zuruflarının usaresinde bulunan juglonun antifungal etki gösterdiğini, bu etkinin orta derecede ve çinko ile selenyum sülfatın etkisine denk olduğunu kaydetmektedirler. 
Yine Tekintaş ve ark. (1988), cevizin ksilem özsuyu içerisinde bulunan juglonun tohum çimlenmesi ve gelişmesi üzerine engelleyici bir etki yaptığını bildirmektedir. Bütün bu çalışmalardan yola çıkarak, bu çalışmada, çimlenme esnasında hücre bölünmesi ve büyümesi olarak görülen meristematik faaliyetler üzerine ceviz floem ekstraktının etkileri belirlenmeye çalıșılmıştır. Dolayısıyla, bu çalışmada ceviz bitkisinin ksilem öz suyunun aşı başarısını etkilemesi ile floemekstraktının fide gelișimini etkilemesi arasında bir ilişki kurulmaya çalışılmıştır.

\section{Materyal ve Yöntem}

Bu çalışmada, çimlendirmek amacıyla Safaa F1 Royal Sluis hıyar tohumu kullanılmıștır. Çimlendirme ortamı olarak, cevizin yıllık sürgünlerinden elde edilen floemekstraksiyonu kullanılmıştır. Ocak ayı içerisinde ve dinlenme döneminde cevizin floem dokusu sıyrlarak etil alkol içerisinde ekstrakte edilmiş ve kuru maddelerine göre hazırlanan stok çözeltiden (Karadeniz, 1993) her petriye $2 \mathrm{ml}$ ekstrak (EKS)+6 $\mathrm{ml}$ saf su (SS); $4 \mathrm{ml}$ EKS + $4 \mathrm{ml} \mathrm{SS} ; 6$ $\mathrm{ml}$ EKS $+2 \mathrm{ml}$ SS ve $8 \mathrm{ml}$ EKS olacak şekilde çözeltiler hazırlanmıştır. Çözeltiler içerisindeki alkolü uçurduktan sonra, bu kapların alt ve üst kısımlarına kurutma kâğıtları yerleștirilerek, bu kağıtlar arasına her birinden 10 adet olmak üzerek hıyar tohumları yerleştirilmiş ve petriye $5 \mathrm{ml}$ saf su ilave edilerek çimlenmeye bırakılmıştır. Çimlenen tohumların gelişmeleri bir cetvel yardımıyla, tohum ekiminden itibaren 8, 10 ve 16 gün sonra ölçülmüştür. Ayrıca, her ölçüm tarihinde kaplara 5 $\mathrm{ml}$ saf su ilave edilmiştir. Diğer yandan, bu çalışmada kullanılan floem ekstraktında toplam fenolik bileşik $13.07 \mathrm{mg} / \mathrm{g}$ düzeyindedir.

\section{Bulgular ve Tartışma}

Farklı yoğunluklarda hazırlanan çözeltilerle muamele edilen tohumların değişik oranlarda çimlendiği görülmüştür (Çizelge 1).

Çizelge 1 incelendiğinde görülebileceği gibi, floeme kstraktıyla muamele edilen tohumlarda çimlenme oranı kontrole göre önemli derecede düşük düzeyde gerçekleşmiş, hatta 6 ve $8 \mathrm{ml}$ EKS ile muamele edilen tohumların hiç biri çimlenmemiştir. Kontrol tohumlarında ise uygulamadan 10 gün sonra \% 100'nün çimlendiği belirlenmiştir. Uygulamadan 16 gün sonraki çimlenme durumu Çizelge 2'de verilmiştir.

Çizelge 1. Farklı yoğunlukta hazırlanan floemekstraktıyla muamele edilen tohumlarda uygulamadan 8 gün sonraki durum.

\begin{tabular}{lcc}
\hline Muamele & 8 gün sonra & 10 gün sonra \\
\cline { 2 - 3 } & Çimlenme durumu (\%) & Çimlenme durumu (\%) \\
\hline $2 \mathrm{ml} \mathrm{EKS+6} \mathrm{ml} \mathrm{SS}$ & 70 & 90 \\
$4 \mathrm{ml} \mathrm{EKS+4} \mathrm{ml} \mathrm{SS}$ & 70 & - \\
$6 \mathrm{ml} \mathrm{EKS+2} \mathrm{ml} \mathrm{SS}$ & - & - \\
$8 \mathrm{ml}$ EKS & - & 100 \\
Kontrol (SS) & 90 & 900 \\
\hline
\end{tabular}

EKS: Ekstrak; SS: Saf Su

Çizelge 2. Uygulamadan 16 gün sonraki çimlenme durumu.

\begin{tabular}{lcc}
\hline Muamele & Sürgün geliștiren (\%) & Kök geliştiren (\%) \\
\hline $2 \mathrm{ml} \mathrm{EKS+6} \mathrm{ml} \mathrm{SS}$ & 90 & 100 \\
$4 \mathrm{ml} \mathrm{EKS+4} \mathrm{ml} \mathrm{SS}$ & 80 & 90 \\
$6 \mathrm{ml} \mathrm{EKS+2} \mathrm{ml} \mathrm{SS}$ & - & - \\
$8 \mathrm{ml}$ EKS & - & - \\
Kontrol (SS) & 90 & 100 \\
\hline
\end{tabular}

EKS: Ekstrak; SS: Saf Su 
Çizelge 2'den de izlenebileceği gibi, saf su uygulanan tohumlarda (kontrol) \%90 düzeyinde sürgün meydana gelirken, tamamında ise kök oluşmuştur. 2 ml EKS'teki sürgün gelişimi \%90 düzeyinde kalırken, bu gruptaki tohumların tamamı da kök oluşturmuştur. $4 \mathrm{ml}$ EKS'de $\% 80$ ve $\% 90$ düzeylerinde sürgün gelişimi ve kök oluşumu görülürken, 6 ve 8 ml EKS'de sürgün ve kök gelișimi olmamıştır. Uygulamadan 8 ve 10 gün sonra meydana gelen plumule (sürgün ucu) uzunluğu Çizelge 3'de verilmiştir.

Çizelge 3'den de izleneceği gibi, çözeltinin yoğunluğu arttıkça, plumule uzunluğunun azaldığı ve $6 \mathrm{ml}$ EKS ile $8 \mathrm{ml}$ EKS uygulamalarında plumulanın hiç gelişmediği görülmektedir. Uygulamadan 16 gün sonra sürgün ve kök uzunluğu Çizelgede 4'de sunulmuştur.

Çizelge 4'de de görülebileceği gibi, uygulamadan 16 gün sonra kontrolde gerek sürgün uzunluğu ve gerekse kök uzunluğu daha yüksek bulunurken, çözeltinin yoğunluğu arttıkça, bu iki parametredeki değerlerin düştügüu, 6 ve $8 \mathrm{ml}$ EKS'de ise sürgün ve kök faaliyetinin hiç olmadığı görülmüştür. Çizelgelerden de anlaşlacağı üzere, cevizin floem ekstraktı tohum çimlenmesi ve fide gelişimi üzerine olumsuz yönde etki etmektedir. 6 ve $8 \mathrm{ml}$ EKS olarak hazırlanan ortamlara başlangıçta ve her ölçüm tarihlerinde ilave edilen 5'er ml'lik saf suya rağmen, bu ortamda hıyar tohumlarının hiç birinde çimlenmenin meydana gelmeyişi, cevizin floem ekstraktında önemli düzeyde engelleyicilerin bulunduğunu ortaya koymaktadır. Yine, kontrol olarak kullanılan saf suda çimlenme oranına göre, diğer seyreltik çözeltilerdeki gerek çimlenme ve gerek fidelerin kök ve sürgün gelişim oranı önemli ölçüde düşük düzeyde gerçekleşmiş, ya da hiç çimlenme meydana gelmemiştir.

Çizelge 3. Uygulamadan 8 ve 10 gün sonra plumule uzunluğu.

\begin{tabular}{lcc}
\hline Muameleler & \multicolumn{2}{c}{ Uygulamadan sonra geçen gün } \\
\cline { 2 - 3 } & 8 gün & 10 gün \\
\hline $2 \mathrm{ml} \mathrm{EKS+6} \mathrm{ml} \mathrm{SS}$ & $18.6 \mathrm{~mm}$ & $31.9 \mathrm{~mm}$ \\
$4 \mathrm{ml} \mathrm{EKS+4} \mathrm{ml} \mathrm{SS}$ & $14.1 \mathrm{~mm}$ & $26.7 \mathrm{~mm}$ \\
$6 \mathrm{ml} \mathrm{EKS+2} \mathrm{ml} \mathrm{SS}$ & - & - \\
$8 \mathrm{ml}$ EKS & - & $54.4 \mathrm{~mm}$ \\
\hline
\end{tabular}

EKS: Ekstrak; SS: Saf Su

Çizelge 4. Uygulamadan 16 gün sonra sürgün ve kök uzunluğu.

\begin{tabular}{lcc}
\hline Muameleler & Sürgün uzunluğu (mm) & Kök uzunluğu (mm) \\
\hline $2 \mathrm{ml}$ EKS+6 ml SS & 15.2 & 58.3 \\
$4 \mathrm{ml}$ EKS+4 ml SS & 11.4 & 43.3 \\
$6 \mathrm{ml}$ EKS+2 ml SS & - & - \\
$8 \mathrm{ml}$ EKS & - & - \\
Kontrol (SS) & 21.6 & 62.3 \\
\hline
\end{tabular}

EKS: Ekstrak; SS: Saf Su

Cevizin floemekstraktında yoğun olarak bulunan fenolik bileşiklerin (Karadeniz, 1993) kallüs kültürü gelișimi üzerine yaptığı inhibitör etkiyi (Prataviera et al., 1983; Hansman et al., 1986), tohum çimlenmesi ve fide gelişimi üzerine de yaptığı ortaya çıkmaktadır. Bitkilerde büyümeyi teşvik eden bu maddeler (Tanrisever, 1982a; Tanrisever, 1982b), ya bitkilerden ekstrakte edilirken oksitlenmekte ve inhibitör bir bileşik durumuna geçmekte, ya da bu madde ancak bitki bünyesinde IAA ve başka birçok bileşik ile beraber büyümeyi etkilemektedir. Zira, floem dokusundan ekstrakte edilen ve bu ekstrakt içerisinde yoğun olarak bulunan fenolik bileşikler, bitki bünyesi dıșına çıktıklarında inhibitör bir etki 
göstermektedir. Öyle ki, aşı başarısının diğer meyve türlerine göre düşük olduğu cevizde, aşllama esnasında kesim yüzeylerindeki fenolik bileşiklerin oksitlenmesi sonucu, meristem faaliyetler engellenerek kaynaşma olumsuz yönde etkilenmektedir (Hansman and Novoa, 1986; Tekintaş ve ark. 1989; Rongting and Pinghai, 1990; Karadeniz, 1993).

Sonuç olarak, cevizin floem ekstraktında yoğun olarak bulunan fenolik bileşikler, tohum çimlenmesi ve fide gelişimi üzerine önemli düzeyde inhibitör etki yapmaktadır. Ceviz floem eksraktının, gelişmesi arzu edilmeyen bitkilerin kontrol altına alınmasında ve bu bitkilerle mücadelede kullanılabilirliğinin araștırılması, kimyasal yöntemlerle mücadeleye alternatif bir boyut kazandırarak sürdürülebilir bir çevreye katkı sağlayacaktır.

\section{Kaynaklar}

Clark, A. M., Jurgens, T.M., Hufford, C. D., 1990. Anti microbial activity of juglone. Hort. Abst. Vol.60, No.9: 7629.

Hansman, D., Novoa, C. 0.,1986. Micropropagation of temperate nut trees. Hort. Abst. Vol. 56, 403416.

Karadeniz, T., 1993. Cevizlerde (Juglans regia L.) flavan içerikleri ile aşı başarıları arasındaki ilişkiler üzerine araştırmalar. Yüzüncü Yıl Üniversitesi Fen Bilimleri Enstitüsü (Basılmamış), Doktora Tezi, Van, 113 s.

Prataviera, A.G., Kuniyuki, A. H., Ryugo, K., 1983. Growth inhibitors in xylem exudates of persian walnuts (Juglans regia L.) and their possible role in graft failure. Journal of the American Society for Horticultural Science, 108(6):10431045.

Rongting, X., Pinghai, D., 1990. Theory and practice of walnut grafting. Acta Horticulturae, 284: 6988.

Tanrısever, A., 1982a. Kiraz grubu Prunus türlerinde flavan içerigi ile büyüme gücü arasındaki ilişkiler üzerinde araştırmalar. Ege Üniversitesi Ziraat Fakültesi Dergisi, 19(2):39-49.

Tanrisever, A., 1982b. Kondanse Tanenlerin Histoşimik Analizlerde Yeni Bir Yöntem ve Fizyolojik Önemleri. Ege Üniversitesi Ziraat Fakültesi Dergisi, 19(2):27-38.

Tekintaş F. E., Tanrısever A., Dalkılıç G.G., 1988. Ceviz çöğürlerinde (Juglans regia $\quad$ L.) ksilem özsuyunun akışı ve Juglon içeriği üzerinde bir araştırma. Ege Üniversitesi Ziraat Fakültesi Dergisi, 25(3):1-11. 